\title{
The Scenes of the Obscene in Contemporary Turkish Art
}

\author{
Elif Çimen \\ Balikesir University, Balikesir, Turkey
}

\begin{abstract}
In contemporary Turkish art, topics or items considered obscene by society are being carried out by a number of artists with protest, agitation, anti-propaganda, or strike purposes. Issues that are often seen in social life such as domestic violence, honour killings, rape, gender discrimination, intolerance against minority groups generate some artists' main theme in their work. Certain circles do not show any reaction to such social wounds, or even support. These circles that have no discomfort in the existence of these wounds get disturbed when they face these social realities through artistic activities. These artists are subject to threats or even physical attacks by such groups. In this paper, Turkish artists, namely Şükran Moral, Taner Ceylan, and Nezaket Ekici who make use of such obscene scenes in their works, will be analyzed including their performances, reactions, and attitudes toward threats and attacks.
\end{abstract}

Keywords: obscenity in art, obscene Turkish art, contemporary art

Art is never chaste. It ought to be forbidden to ignorant innocents, never allowed into contact with those not sufficiently prepared. Yes, art is dangerous. Where it is chaste, it is not art.

-Pablo Picasso,

Picasso (1963)

\section{Introduction}

This paper addresses the artists and works that have been facing resistance by the society due to so called "obscenity", by observing the concept of obscenity and its development throughout the history, and also referring to possible ways to overcome this situation. Within this perspective similar various problems in Turkish and world art have been exampled and examined. Finally, we tried to shed light on the situation with interviews with artists.

\section{Obscenity in the Global Sense}

Since prehistoric times, nudity and erotic themes which are considered obscene have been expressed in both scholastic and primitive art. Through the development of technology, humanity has become advanced in communications, transportation, housing, and nutrition, yet humanity continues to debate what is "obscene" and the boundaries of freedom in art are shrinking each day rather than expanding. In order to observe this phenomenon, it is helpful to identify the concept of obscenity in historical, anthropological, and geographical context.

Like children, people in primitive societies do not have a sense of shame sourced by nudity. Shame is a cultural phenomenon and it is learnt over time. Sociologist König (1958) supports this idea by saying "shame is

Elif Çimen, professor, Department of Painting, Faculty of Fine Arts, Balikesir University. 
an emotion that emerges in a very high stage of culture" (p. 147). Historians and anthropologists discuss whether or not shame existed in primitive societies within a patriarchal perspective in general. Sociologist Elias (2000) stresses that shame had not developed until the contemporary age, saying "the less distinction between public and private spaces exists in a society, the more primitive it is" (p. 269). In contrast, anthropologist Duerre (1997) claims that shame is an instinct since birth saying "however defined nudity historically, being ashamed of self nudity lies in the essence of human" (p. 13). In 1926, anthropologist and ethnologist Levi-Strauss (2004) examined the natives living in the Amazon region, and described one of the indigenous tribes, Nambikwara, as everyone living minimally, naked and with few oddments and their only outfit being jewelry made from plants and cotton strips around the waist and arms, instead of proper clothing (s. 267). If the tribal members had been ashamed of being nude or if their nudity had sexual connotations sufficient to disrupt daily life the people of the tribe would not have spent their time together naked. Here, we can reach the conclusion that nudity is not against to the nature of humanity.

On the phenomenon of nudity in the Hellenistic culture, in his book Skin and Stone Sennett (2002) talks about the meaning of nudity to urban dwellers in the most glorious days of ancient Athens and says that the "nude and exposed body is usually accepted as an emblem of self-confident people that feel at home in their city" (p. 17). Along with the dominance of patriarchal systems (since goddesses are expulsed from Olympos and have been replaced by gods) a phenomenon occurred that separated the inside and outside home. Millett (1973), in her book Sexual Politics, claims that the expulsion from heaven, which is in fact the main mythos of Judeo-Christian (as well as Islamic) imagery, is a further developed version of the myth of Pandora from the Hellenistic mythology, where the women are blamed for sexuality and held responsible for the first sin (p. 93). In the same book, she says "In a certain period of the ancient culture, the goddesses of fertility were replaced by the patriarchal gods" (p. 92).

Sennett (1999) on the separation of public and private life (inner and outer world) in The Conscience of the Eye, attempts to explain the emergence of the fear of exposure, and the wall between the inner and outer life:

This wall exists partly due to our religious preference: Christianity led the western culture to a position that a wall is raised between the inner and outer life. Secular society is still darkened in the shadow of this wall.... The visible external life of the city is not a reflection of the inner life. (p. 15)

The interior of a person's home has been declared confidential and private. While this concept provides freedom of movement inside the house, in some unfortunate circumstances, it also brings freedom of violence, harassment and humiliation. Inside the house, people who are defenseless, often the elderly, women, and children, may remain exposed to violence or sexual harassment. These same people walk on the streets as if there were no problems and go to the work and school. So, can the separation of public and private spaces in society be called "civilization" as claimed by Elias? Do such people in severe distress come from the high culture König descibes? Levi-Strauss (2004) provides a very different description of the people that Elias labels as "primitive": "Locals are almost always cheerful and smiling, joking with each other..." (s. 294), "The children are never punished and I never saw any of them being beaten or even threatened other than jokes..." (p. 296), "Locals feel and express a very sincere affection towards their children and also get the same reaction" (pp. 295-296). Is it possible to call such a loving social structure "primitive"?

Today, we are surrounded by signals telling us that nothing will stay hidden with the spread of means of communication. Any problem that occurs within the house (violence, etc.) can rarely be kept secret anymore. 
Yet still, a work of art can be declared "obscene" just because it contains an image or idea that is taboo. There are those that seek to criminalize certain artistic expression as "obscene" when that expression raises dark and uncomfortable truths about subject matter that society deems highly private. The happy minority of society, often playing three monkeys, ignores the violence, discrimination and racism that happen around them. For example, Turkish people often choose to ignore the ugly reality of "female circumcision", a common practice in some Middle Eastern and African countries, because the practice does not typically occur in Turkey. They ignore the artists who address these issues. Such artists have even been sued or threatened. Despite negative reactions, artists continue to wake up and shake up society. Artists try to reveal the things that are hidden and to create awareness. Artists keep alerting society, sometimes agitating, sometimes protesting or even using their own bodies for artistic expression.

According to Western writers, the effect of the definitions of "decency", "shame", and "obscenity" on the perception of the human body, is initiated by the Jewish-Christian understanding of concepts. Foucault (2003) implies that the continuing dedication to chastity, stiffness of sexuality, and the silence and hypocrisy surrounding sexuality come from the Victorian era. Is not it ironic to refer to this strict patriarchal structure of society with the name of a woman, Victoria, and thus place the blame for this society on a queen who reigned only 63 years? However, Millett (1973) points out that the patriarchal structure has existed for of thousands of years saying:

It shouldn't be forgotten that the people were led to a deep depression because of the sexual repression in the "chastity" concept in the last years of Victorian era and the only alternative was to get rid of "chastity" all together. (p. 107)

\section{Obscenity Issue in Global and Turkish Art}

Many artists have been producing a variety of works and performances, exposing their personal life, using the body or body wastes as an object when necessary. The ones who address the role of women are usually feminists. Some of them struggle to have a place in the current art world system which can be considered oppressive and closed to females. Other feminist artists also struggle against the system in order to change it. Artists producing with the aims of drawing attention to injustice and anti-democracy, asking for rights, pushing society become aware, often face protests, attacks, bans, and censorship in many countries of the world. For example, in London in 1971, the first solo feminist exhibition by Margaret Harrison was shut down by the authorities, claiming that a drawing of a male character representing Playboys founder and editor Hugh Hefner portrayed as a "Bunny girl" with a "Bunny penis" (Chadwick, 2007, p. 355) was considered "offensive" material. Similarly, a work named "God Giving Birth" (1969) by artist Monica Sjoo was the target of threats and allegations of insult and obscenity (p. 373).

Another dimension of inequality in art is the critical response to the work produced by female artists on their own bodies compared to the male artists who do the same. For example, in U.S. in 1971, critics acclaimed Chris Burden's performance in which he had a friend shoot him and Vita Acconci's performance involving masturbation beneath a wood flooring stating that the performances "forced both artistic and physical limits, tested the limits of man's power" (Chadwick, 2007, p. 367). By contrast, the same year, Gina Pane's performance involving sharp and injurious objects, when she climbed up a ladder with bleeding hands and feet, was criticized as an abnormal and a masochist experiment, even by feminist critics (Chadwick, 2007, s. 367). Similarly, Marcel Duchamp's "Etant Donnes" met with great enthusiasm by critics, while ten years later "The Dinner Party", a famous work of Judy Chicago which featured vagina like imagery, was derided as being pornographic until much later in the 1990s. 
In Turkey where art education happens without the nude models (which Mehmet Yilmaz analogizes to learning surgery without cadavers), and where citizens attack art galleries and assault art lovers, we are asked to be optimistic towards the fact that we can continue to produce art despite these challenges. Even on the social network Facebook, Turkish sculptor Deniz Ilgaz's “construction” where she covers her body in mud, is being censored and removed. Publications that deal with issues declared obscene by the law are put in black packets under the Children Protection law. However, as said by Turkish woman artist Şükran Moral "there is so much evil that the children should be protected against" (personal communication, March 15, 2012) (lack of education, violence, hard labor, harassment, etc.). Against all the odds, brave artists emerge even though their work may be labeled obscene. Some of the artists that have been accused of obscenity are Canan Şenol, Mehmet Yılmaz, Nezaket Ekici, Kutluğ Ataman, Taner Ceylan, and Şükran Moral. This article will address the work of the latter two.

\section{Two Turkish Artists and Their Divergent Works}

Şükran Moral is a feminist artist who has questioned the structure of patriarchal society, values, norms, and rules since the early 1990s. Migrations, the subversion of iconographic scenes, and sexual identity, are some of the topics she addresses. She also addresses the status of women and violence against women. She believes that the Eastern societies have developed hate against women: "People are afraid of woman orgasm. People are afraid of woman sexuality. People are afraid of women that get in a relationship with more than one man” (personal communication, March 15, 2012). Moral argues that violence against women is not only a problem in Eastern countries and Turkey, but a universal one that exists in countries such as France and Germany. Her performances exposing the plight of Muslim girls and women of the Middle East consists of the works, "The Dark Family", “Adultery" and "Here's Guilty!" In one performance, a veiled woman played by her destroys the books and crayons belonging to a little girl (the destruction of the imagination) and throws stones at the girl. On the wall is a portrait of the bearded father of the family. Moral's message is this: The vagina is guilty, "Here's Guilty!" reflects this without the need of any metaphors. Moral's three years in Italy as a fugitive after her deportation from Italy shook her deeply. Moral describes her distress in "Artista": "I wanted to tell the suffering that I took by identifying myself to Jesus Christ. This is also a revolt in strictly Catholic Italy. I have put myself in place of their Allah" (personal communication, March 15, 2012).

Moral's performance "Amemus", consisted of the artist making love to another woman for 20 minutes in front of the viewers, as well as the "performance" being photographed and recorded on video. Surprised and shocked, some of the viewers left the gallery. The next day news web sites screamed headlines such as "Lesbian sex at the gallery opening!" and "Sex scandal". She evaluated the responses she received as she reached her goal. Moral, not well known to the Turkish public prior to "Amemus" is now engraved in everyone's minds.

The first traces of Moral's work pushing the boundaries of obscenity can be captured in the 1997 work "Bordello", in which the artist acted a 24-hour performance at the door of a brothel, with the door plate "a contemporary art museum", and holding a paper that read "for sale". Moral juxtaposed the concepts of a "museum" and the "artist" with the concepts of "brothel" and "whore". Her performance was also a subtle critique of art history.

During an interview, Moral was asked for a description of the philosophy behind her works which have been subject to criticism or even been declared "obscene" by law. Moral responded that her creativity has been 
influenced by her cultural baggage and personal experiences, and in her projects we can find reflections of the Renaissance:

There is no coincidence in Hammam video's scenes. One can come across traces of Caravaggio, and even the frescoes on Pompei's walls in Naples. Also Body Art or Dada, but I can also forget it all when I am doing art. Hegel, Nietzsche and postmodernism ... Is it possible not to be affected by them? (personal communication, March 15, 2012)

She says it is the intercommunication era, adding "the evolution of humanity is phenomenal. The artist must be further than her era, even if she is lapidated. This is my philosophy!" (personal communication, March 15, 2012).

About the performance "Love and Violence" which was slipcased by authorities, Moral notes:

It is about a little girl's transformation and all the violence she is exposed to. First she is withdrawn from school, then the genital mutilation of her clitoris is carried out by her mother followed by the marriage to an old man. (personal communication, March 15, 2012)

She draws attention to the scale of the child bride issue which has recently been the theme for a TV drama series in Turkey:

At the time it was insisted that there was no such thing in the boundaries of Turkey. In the performance acting as the mother, I hit myself with a rubber whip in terms of punishment and hit the ground with the last stroke. (personal communication, March 15, 2012)

She claims art has turned into botulin (Botox) these days and calles it "botulinart", she says, it is bright but empty. She emphasizes that it is a decorative element which tries to maintain the balances.

Moral's work "That's the criminal", an image of a vagina with scattered blood, is a protest against violence. If protest is considered as provocation, there is not much for her to say. "It's their problem! I'm not an artist of the palace" she adds. "Gynecology Chair", first exhibited in 1996 in Italy, followed by the Istanbul Biennial in 1997, is a striking work because of its implications. The artist states, "Such radical works unfortunately have to wait for many years before gaining value. As in the Bordello performance" (personal communication, March 15, 2012).

About the use of elements in her performances that can be considered obscene in Turkey, Moral claims that obscenity varies from society to society:

One could find two tomatoes and a cucumber obscene, while for someone else this reasoning could indicate a "mental illness". The vagina in blood highlights the hypocrisy of the society reflecting the truth that "virginity is still being sought, and rape is still an issue, and that if rape and violence are not obscene, but to expose them is; then I feel as an artist, I must continue to do what I believe. (personal communication, March 15, 2012)

When asked if it is a coincidence that the ones who mark art works as obscene, indecent, obnoxious are usually hostile to art and artists in general, Moral replies "if you mirror the society, it is inevitable for them to be annoyed" and mentions the installation "Dark Family" which consists of a table covered with papers full of news of violence and over them lay a bunch of weapons used in the killings of women. "A screaming skeleton of a woman was sitting by the table and watching her end" says Moral and adds, "The power of art lies in the presentation of truth with a new synthesis, the ones who define art with their narrow moral standards, also present the enemies of art. Hitler burned paintings in public squares" (personal communication, March 15, 2012). Following her recent performance of "Amemus" that took place in Turkey, Moral has been threatened 
with murder and has been exposed to media lynching attempts. Moral also experienced attacks and interference during the performance, but she is accustomed to such instances. Moral states that it is sometimes tough to find locations to perform her works, but she does not wish to work with just anyone either. On media reactions and reviews she points out that columnists sometimes go as far as "spit on Şükran Moral", but she also states there is an audience that understands and recognizes her work.

Taner Ceylan is a record-priced artist who has shaken the taboos in Turkey about art and obscenity. From an early age, he has experienced some difficulties in Turkey, due to his sexual orientation. Even with support from his family, he faced negative reactions from many others which added to his feeling of exclusion. After graduating from Mimar Sinan University with honours, the artist had a difficult time finding a gallery willing to work with him, or a printing house that would print his catalogues, due to his "obscene" works. Even Yeditepe University terminated his employment due to the controversial nature of his art. His circumstances changed after the eighth Istanbul Biennale.

In an interview, Ceylan explained that his works that challenge the idea of obscenity are based on his own life experience and the life he wishes to experience. There was a lawsuit against a gay-lesbian magazine in Turkey that published his work "Taner-Taner" in which the artist portrayed himself making love to himself. Ceylan pointed out that even though the case was dropped because the magazine had not yet been distributed, the publishers held Ceylan responsible for the printed work.

Taner-Taner came to life after it was included in an exhibition themed "Unique to Family". He thought to himself, what if he was his own family and he made love to himself. "I am careful about not inventing the wheel all over again. The society's deficiencies are not a concern of mine. I would not be painting in some other way even if I lived in Japan" (personal communication, March 15, 2012).

Ceylan states that art is only appreciated after articles are written about it, and it becomes a part of a museum "The work itself is an excuse for attacking the maker. For, the work is perceived as a threat to social order" (personal communication, March 15, 2012). About works being called obscene, "In a sense, these bend over the society. In the 1990's my paintings were struggling in the art world, now eroticism is found more often in Turkish art" he says, "I think hostility towards art stems from the religious and social traditions, domestic violence, honor killings, sexual discrimination also is the extension of religious and social traditions".

His painting "1923" referring to Ottoman Pashas caused a sharp reaction. "The art has a universal language. This is the official language and does not need an extra subtext" Ceylan says, and for judgments against his work "I preserve my composure, I continue to produce. Otherwise I would fail". He claims that he is always good with the ordinary audience that negative responses in general come from the intellectual audience: "I know there is a mass that appreciates and rewards me". About the difficulty in finding venues for exhibiting his art: "Galleries at the beginning of the nineties did not want to exhibit my paintings, they were conservative and fearful. I passed the exams over time today I choose the gallery I want to work with" (personal communication, March 15, 2012).

When asked if underlining the definitions a "quiet lifestyle", the "decent life" or even "the good child of the family" help dealing with the hostile manners and attacks, Ceylan responded:

My art is a fantastic fiction caused by my hunger, such as Narcissus's falling for his own reflection on the water. The real world does not attract me. I don't understand politics and sociology. I do not know football. I do not follow the economy. I keep track of important exhibitions around the world. When I can't put a painting out of my mind, I've got to 
face with the original. When we come together with friends the only thing we talk about is art. (personal communication, March 15, 2012)

and says,

I'm practicing yoga and meditation. I'm looking for ways to establish contact with God. I'm trying to take control of my soul and depressions. I have seven cats, a garden house outside of town, I live by the sea. My life is my choice, I cannot lie. (personal communication, March 15, 2012)

\section{Conclusion}

Universally art and artist stands at a point that is susceptible to be misunderstood or labeled since their existence; and are often targets of harsh criticism and offensive behavior. Turkish artists, specifically the ones who meddle with alternative art forms, have also been taking their share of this negativity; and they have been struggling to stand up to it, just like their global counterparts. In this paper we tried to address their problems as a means of publicizing and supporting their struggle, concentrating mainly on the ideas and experiences of two Turkish artists. It appears that the problems artists face, especially who choose to produce art with obtrusive content, are far from over. Though, the struggles and methods of coping with challenging situations of artists will hopefully enlighten future generations.

\section{References}

Antmen, A. (2009). Yüzyll bati sanatinda akimlar (Movements in the 20th century western art) (2nd ed.). İstanbul: Sel. Atakan, N. (2008). Sanatta alternatif arayışlar (Atlernative searches in art). (Z. Rona, Trans). Izmir: Karakalem Kitabevi. Barnard, M. (2002). Sanat, tasarim ve görsel kültür (Art, design and visual culture). (G. Korkmaz, Trans.). Ankara: Ütopya. Chadwick, W. (2007). Woman, art, and society (4th ed.). Singapore: Thames and Hudson.

Duerre, H. P. (1997). Çıplaklık ve utanç uygarlaşma sürecinin miti (Nudity and shame, the myth of civilization process) (4th ed.). (T. Onur, Trans.). Ankara: Dost.

Duerre, H. P. (2004). Mahremiyet uygarlaşma sürecinin miti II (Privacy, the myth of civilization process II). (M. Tüzel, Trans.). Ankara: Dost Kitabevi Yayınları.

Elias, N. (2000). Uygarlık süreci (Civilization process). (E. Ateşman, Trans.). Istanbul: İletişim.

Foucault, M. (2003). Cinselliğin tarihi (The history of sexuality). (H. U. Tanriöver, Trans.). İstanbul: Ayrıntı.

Frazer, J. G. (1991). Altın dal dinin ve folklorun kökleri I (The golden bough, the roots of religion and folklore I). (M. H. Doğan, Trans.). Istanbul: Payel.

Frazer, J. G. (1991). Altın dal dinin ve folklorun kökleri II (The golden bough, the roots of religion and folklore II). (M. H. Doğan, Trans.). Istanbul: Payel .

Gouma, T., \& Mathews. P. P. (2008). Sanat ve cinsiyet sanat tarihi ve feminist eleştiri (Art/Sexuality, art history and feminist criticism). (E. Soğancılar, \& A. Antmen, Trans.). Istanbul: İletişim.

Haviland, W. A. (2002). Kültürel antropoloji (Cultural anthropology). (H. Inaç, \& S. Çiftçi, Trans.). Istanbul: Kaknüs.

Kahraman, H. B. (2005). Cinsellik görsellik pornografi (Sexuality visuality pornography). İstanbul: Agora.

Levi-Strauss, C. (2004). Hüzünlü dönenceler (Tragic tropics) (4th ed.). (Ö. Bozkurt, Trans.). Istanbul: Yap1 Kredi.

Lucie-Smıth, E. (2000). Judy Chicago an American vision. New York: Watson-Guptill.

Malinowski, B. (1992). Vahşilerin cinsel yaşamı (The sexual life of savages). (S. Özkal, Trans.). Istanbul: Kabalcı.

Mey, K. (2007). Art and obscenity. London: I. B. Tauris.

Millett, K. (1973). Cinsel politika (Sexual politics). (S. Selvi, Trans.). Istanbul: Payel.

Sayin, Z. (2003). Imgenin pornografisi (The pornography of image). Istanbul: Metis.

Sennett, R. (2002). Ten ve taş bati uygarliğinda beden ve şehir (Flesh and stone: The body and the city in Western civilization). (T. Birkan, Trans.). Istanbul: Metis.

Sennett, R. (1999). Gözün vicdani kentin tasarımı ve toplumsal yaşam (The conscience of the eye: the design and social life of cities). (S. Sertabiboğlu, \& C. Kurultay, Trans.). Istanbul: Ayrıntı.

Sezer, M. Ö. (2010). Masallar ve toplumsal cinsiyet (Tales and social sexuality). Istanbul: Evrensel Basım Yayın. 
Taylor, S. (2008). Fobik nesne:Güncel sanatta iğrendirme (Phobic object: disgust in contemporary art). (M. Danal1, Trans.). Istanbul: Resmi Görüş A4 Ofset.

Vallentin, A. (1963). Picasso. London: Cassell.

Yılmaz, M. (2011). Sakıncalı, çünkü edepsiz (Objectionable because impudent). Ankara: Ütopya. 